\title{
Studia
}

SYNCHRONICZNE I DIACHRONICZNE ASPEKTY BADAŃ POLSZCZYZNY

www.wnus.edu.pl/sj | DOI: 10.18276/sj.2017.16-01 | 5-27

\section{KWIRYNA HANDKE}

Warszawa

krhandke@poczta.onet.pl

\section{Skrzydła - wyraz i nośnik symboli w tekstach Stefana Żeromskiego}

\author{
Słowa kluczowe \\ pisarz, tworzywo językowe, skrzydła
}
Keywords
writer, linguistic material, wings

Tworzywo językowe zawarte w tekstach literatury pięknej może być, i bywa, rozmaicie postrzegane przez badaczy. Językoznawcy najczęściej zwracają uwagę na elementy słownikowe, specyficzne nazewnictwo czy określone formy gramatyczne lub słowotwórcze, a także na tekstową funkcjonalność poszczególnych leksemów czy form lub ich grup albo zbiorów tematycznych. Niektórzy śledzą również tropy stylistyczne, zwłaszcza metafory i porównania. Rzadziej spotykamy analizy wykraczające swoim zasięgiem poza tekst literacki jako płaszczyznę penetracji badawczej, czyli poza relację: tekst-badacz. Tymczasem ujęcie szersze, w którym uwzględni się trójstronną relację: pisarz-tekst-badacz, pozwala dostrzec więcej aspektów niemal każdego badanego zagadnienia czy tematu. Przy tym pisarza należy tu postrzegać nie tylko jako autora, kreatora tekstu, nadawcę komunikatu, twórcę oryginalnego warsztatu pisarskiego, ale również jako jednostkę ludzką, egzystującą w określonym czasie i miejscu/miejscach, osobowość o określonej tożsamości, obdarzoną swoistymi cechami, mającą określone upodobania, poglądy i preferencje.

$\mathrm{Z}$ tak nakreślonej perspektywy przedstawię tutaj wybraną jednostkę językową (będzie to wyraz skrzydło, częściej używany, ze względu na parzystość tego narządu, w formie 
liczby mnogiej skrzydta, oraz pochodne formy skrzydlaty, uskrzydlony i wyjątkowo pojawiający się czasownik uskrzydlić), która występuje w zbiorze tekstów jednego pisarza. Nie przypadkiem jest nim Stefan Żeromski, ponieważ potrafił zawrzeć w swoim piśmiennictwie niespotykane gdzie indziej w literaturze polskiej bogactwo słownictwa - różnorodnego słowotwórczo, semantycznie i funkcjonalnie.

Skrzydła w dziejach kultury człowieka mają szczególne znaczenie - jako atrybut świata żywych stworzeń (ptaków, owadów, a nawet niektórych ssaków, takich jak nietoperze), którego nie posiada, a bardzo chciałby go mieć, człowiek. Od zarania dziejów ludzie obserwujący możliwości, jakie dają skrzydła, dążyli do ich naśladownictwa, ale zarazem w swojej bezsilności przypisywali im różnorodne symboliczne treści. Poczynając od starożytności, przedstawiano ze skrzydłami istoty „,ziemskie” niemogące latać, np. skrzydlatego rumaka Pegaza czy mitycznych Hermesa-Merkurego i Perseusza z uskrzydlonymi stopami, czy Dedala i Ikara podejmujących próby lotów do słońca ze skrzydłami przymocowanymi do ramion. Wielowiekowe dążenie człowieka do naśladowania skrzydlatych stworzeń miało $\mathrm{u}$ podstaw marzenie o uniesieniu się z ziemi i lataniu. Ujmując rzecz dowolnie, w syntetycznym skrócie, można przywołać na gruncie polskim taką sekwencję dziejowych faktów: od pradawnego wyrazu *kridlo, wywodzącego się od czasownika o znaczeniu 'latać', do metaforycznego określenia Polskie Skrzydła jako nazwy narodowego lotnictwa.

Obok konstruktywnego nurtu cywilizacyjnego, który pozwolił urzeczywistnić pierwotne marzenia człowieka o lataniu, równolegle rozwijała się sfera symboliki związanej ze skrzydłami. Jak rozległy był jej zakres, ukazuje zbiór zgromadzony w Słowniku symboli ${ }^{1}$. Na początku hasła skrzydła Władysław Kopaliński wymienia to, co one symbolizują: życie, śmierć, posłańca bogów, duszę i ciało, Ducha Świętego, uduchowienie; myśl, umysł, ideę, abstrakcję, ewolucję duchową, inteligencję, wiedzę, rozmyślanie; światło, oświecenie, wyobraźnię; powietrze, wyzwolenie (z przyciągania ziemskiego), wzlot, ulgę, uniesienie, aspiracje, wzniosłość, egzaltację, zapał i wiele, wiele innych. Z kolei rozmaite konkretyzacje tych uogólnień znajdujemy od najdawniejszych czasów w kulturze ludzkości. Niektóre z nich przetrwały w piśmiennictwie i świadomości poszczególnych społeczeństw, znalazły również odzwierciedlenie w znakach językowych, jak np. skrzydła gołębicy (Psalm 54), opiekuńcze skrzydła; brać kogoś pod swoje skrzydła („,Pod cieniem skrzydeł Twoich chroń mnie", Psalm 16); na skrzydłach wiatru (łac. super pennas ventorum), czyli z największą szybkością (Wulgata, Psalmy 17; 103); skrzydlate słowa - metafora pojawiająca się wielokrotnie u Homera w Iliadzie i Odysei; dziś 'słowa, wyrażenia powszechnie cytowane’2.

Polszczyzna wiele odziedziczyła z tego dorobku kulturowego i wzbogaciła go w swojej długiej historii. W efekcie mamy bardzo rozbudową sferę znaczeniową wyrazu skrzydło i form pochodnych, udokumentowaną w leksykonach.

\footnotetext{
${ }^{1}$ Władysław Kopaliński, Stownik symboli (Warszawa: Wiedza Powszechna, 1990).

2 Tamże.
} 
W piśmiennictwie Żeromskiego (z wyjątkiem listów i publicystyki) znalazłam 257 kontekstów, w których pojawił się wyraz skrzydło i pochodne - w różnych znaczeniach i funkcjach tekstowych. Może nie jest to zbyt duża liczba jak na rozmiar tekstów tego pisarza ani nawet w stosunku do zgromadzonego przeze mnie zbioru słownictwa dotyczącego świata zwierząt ${ }^{3}$, jednak mimo to z pewnością godna zauważenia. Konteksty występują we wszystkich rodzajach utworów, choć z niejednakową częstotliwością. Najrzadziej w dramatach, przy tym w ogóle ich brak w Białej rękawiczce, Turoniu i Uciekła mi przepióreczka. W opowiadaniach i utworach powieściowych znaleźć można nieliczne i tylko w niektórych tytułach. Natomiast wyraźnie zauważalną liczbę takich kontekstów mają następujące teksty: Międzymorze (13), Wiatr od morza (14), Uroda życia (17), Dzieje grzechu (20), Duma o hetmanie (21), Popioły (40) oraz Dzienniki (35). Z kolei rozkład semantyczno-funkcjonalny tego zbiorku przedstawia się następująco: w znaczeniach podstawowych (46), w różnych metaforycznych związkach wyrazowych (150) i w porównaniach (61).

W analizie interesowała mnie relacja tego zbioru z tekstów Żeromskiego do zasobu ogólnopolskiego, jaki utrwaliły wielkie leksykony. W porównaniach posłużyłam się Słownikiem języka polskiego pod redakcją Witolda Doroszewskiego ${ }^{4}$, w którym wyraz skrzydło dokumentuje 11 znaczeń i wiele frazeologicznych ${ }^{5}$ związków wyrazowych, oraz Słownikiem frazeologicznym języka polskiego Stanisława Skorupki ${ }^{6}$, w którym przywołano 43 związki z tym wyrazem. W dalszym przedstawieniu materiału przyjmuję kolejność i definicje znaczeń według SJPD.

W znaczeniu podstawowym wyraz skrzydło to 1. 'narząd lotu u niektórych zwierząt kręgowych i bezkręgowych, mający różną budowę i pochodzenie, występujący zawsze w parzystej liczbie (jedna, dwie pary)'.

U Żeromskiego w opisach otaczającego świata prawie nie spotykamy prostych informacji. Jego przedstawienia są zazwyczaj rozbudowane, nierzadko stanowią obrazy czy scenki, zawierają kształty, barwy, dźwięki i przede wszystkim ruch. Dotyczy to również obrazowania skrzydeł. W obrębie tego podstawowego znaczenia wyrazu pisarz opisuje przede wszystkim skrzydła różnych ptaków, takich jak: bekasy, cyranki, kondory, kraski, kruki, kulony, słowiki, szczygły, wilgi, wrony, wróble, żołny, a najczęściej jaskółki, kaczki, mewy, rybitwy, orły i sępy, ale również skrzydła owadów: motyli, ważek, much, a nawet takich latających ssaków, jak nietoperze. Warto przy tym podkreślić, że pisarz doskonale znał świat latających stworzeń, ponieważ obserwował go od dzieciństwa. Później często bywał nad morzami (we Włoszech, we Francji, w Polsce), stąd tak wiele miejsca poświęcał mewom i rybitwom.

\footnotetext{
${ }^{3}$ Będzie to kolejny, zapewne 17., tom serii Stownictwo pism Stefana Żeromskiego.

${ }^{4}$ Stownik języka polskiego, red. Witold Doroszewski, t. I-XI (Warszawa: PWN, 1958-1969); dalej skrót SJPD.

${ }^{5}$ Związki frazeologiczne w rozumieniu SJPD, zob. t. I tego Stownika.

${ }^{6}$ Stanisław Skorupka, Stownik frazeologiczny języka polskiego, t. I-II (Warszawa: Wiedza Powszechna, 1989).
} 
Ze względu na oczywisty przedmiot przedstawień istotne są kształty skrzydeł, a przede wszystkim ich ruchy, które pisarz oddał bardzo dużą liczbą czasowników, wpisanych w rozmaite konteksty, np.:

dotykać skrzydłami, kołysać się na skrzydłach, lecieć, latać, łopotać, mieć skrzydła, migać, ogarnać, okryć, otaczać skrzydłami, otworzyć, podawać skrzydła, porwać na skrzydła, potargać skrzydła, przefrunać, przemierzyć na skrzydłach, przenosić na skrzydłach, przypiać, przyprawić skrzydła, rozłożyć, rozpościerać, rozwijać, trzepać, unosić się na skrzydłach, ważyć się na skrzydłach, wyfrunać, wyłamywać, wynosić się na skrzydłach, wznieść się, wznosić się, zwichną́, zwiesić skrzydła (zob. też dalej dźwięki wydawane skrzydłami).

Jak za dni naszych mewy białoczelne nad jej [Prawisły] szerokim wodnym przestworem rytmem rwanym, w sposób niewysłowienie uroczy, miotają skrzydta dlugie $i$ wydaja krzyk swój bojowy (Międz 308)7

Widzę tuż nad swą głowa rozpostarte jej [mewy] skrzydła, dziób rozwarty, słyszę krzyk chrapliwy i dziki (Międz 297)

Nad ciemna woda rozjuszona migaja skrzydła mew, padaja niemal w fale i znowu szybują ku chmurom [Capri, burza nad morzem] (Zapis 163)

[rybitwa] Ja jestem [...] ptak przelotny, którego skrzydta burza z prawa i z lewa podbija (Międz 298)

Radowat go rozmach skrzydet chyżej, wiatroskrzydtej rybitwy, co się nad rozlewiska Wisty z morza dalekiego wybrała (Wiatr 75)

[...] rytmicznie wyrzucając do lotu skrzydła kołysza się kulony (Zap 75)

Proste, wysmukłe sosny kiwaja [...] gałęziami, po których tułaja się z rozpostartymi skrzydtami młode wrony, zabawnie udajac doroste (Dzien II 293)

[pies Puk] goni lekkoskrzydłe jaskółki (Pom 140)

[...] uwage wszystkich skupił na swych lotnych skrzydłach motyl, biały jak płatek śniegu. Kiedy niekiedy przytulat piersi do badyla $i$ wtedy leniwie poruszat skrzydtami, jakby się nimi wachlowat (Prom 114)

[...] krasnopióre żotny, które w lot zabijaja lekkoskrzydłe motyle $i$ ociężałe żuki (Wiatr 60)

Z ruchem skrzydeł łączą się wydawane przez nie dźwięki, które są słyszane i rozróżniane przez uważnego obserwatora, dodatkowo obdarzonego dobrym słuchem i muzyczną

7 Wszystkie cytaty pochodzą z: Stefan Żeromski, Pisma, red. Stanisław Pigoń (Warszawa: Czytelnik, 1947-1956); tenże, Dzienniki, t. I-III (Warszawa: Czytelnik, 1953-1956); tenże, Listy, oprac. Zdzisław J. Adamczyk, w: tenże, Pisma zebrane, t. 34-39 (Warszawa: Czytelnik, 2001-2010). 
wrażliwością, a takimi cechami odznaczał się Żeromski ${ }^{8}$, dzięki czemu mógł przedstawić tak różnorodną gamę dźwięków wydawanych skrzydłami stworzeń latających, np.:

Już nie świszczą ponad konarami skrzydła orłowe (Pop I 9)

Stado wron z topotem skrzydet i krakaniem [...] drapało się na wysokie szczyty włoskiej topoli (Pop II 164)

Z wyżyny wiązu rosnacego w kacie ogrodu spada trzepocac skrzydłami złotolita wiwilga i broczy krwia mokre trawy (Pop I 11)

Posypały się ciężkie krople rosy na okragłe głowy koniczyn, na smółki wysmukłe i przyziemny barwinek, gdy z łoskotem skrzydet w koronę sosny zapadła [wilga] (Wil 256)

[nad wodami i moczarami] najżywszą melodię życia wydzwania chyże skrzydto dzikiej kaczki (Wis 13)

Nadleciały stadkiem cyranki, krążyty kilkakroć z wyciagniętymi szyjami, przerywając cisze melodyjnym, dzwoniacym świstem skrzydet, zataczaty w powietrzu elipsy coraz mniejsze - wreszcie zapadty $w$ trzciny, z łoskotem rozbijajac wodę piersiami (Zmierzch $54 / 55)$

Park byt pusty i cichy zupetnie [...] Tylko ptaki wołały się po drzewach. Niektóre z nich pędzity za żerem w wysoka trawę i od czasu do czasu przerywaty ciszę trzepotem skrzydet, gdy uczepiwszy się grubych badylów bujaty wraz z nimi na powietrzu (Syz 230)

[Rafał w Wygnance] Gdy nieraz leżał na suchych pagórkach, otaczajacych niskie łąki nadrzeczne [...] wysoko pod chmurami dawat się styszeć chrzęst skrzydeł bujajacego bekasa (Pop I 149)

Ucicht dudniący lot bekasów (Zmierzch 55)

Czasami kędyś w lazurowej wyżynie rozdzwaniat się podchmurny klangor skrzydet stada dzikich kaczek-krzyżówek krążacych ostrożnie nad wodami [nad Wisłą] (Char 150)

[Śnica obserwujący loty kaczek] Wy, piękne ptaki [...] Jakże jest pięknie, gdy lecicie na skrzydłach dzwoniacych! (Char 151)

[Helena w górach] [...] śpiewała pieśń złożona z dziwnych słów. Nazwy uwielbiające moc wichru, pochwały piękności jako wybuchów ptynęty z jej piersi tak samo jak owe śliczne a niespodziewane chmury z łona gór. W ustach zmieniały się na śpiew solowy, dostrojony do melodii szumnych poświstów, do niezglębionych akordów ryku puszcz wylatujacego z dolin ku niebu, a w którym stychać jakby śmiganie olbrzymich ptasich skrzydet po niezmierzonych obszarach (Pop II 80)

${ }^{8}$ Zob. Barbara Bartnicka, Świat dźwięków, t. 4. serii Słownictwo pism Stefana Żeromskiego (Kraków: Universitas, 2002). 
Muszki przelotne [...] Przecinaja skrzydłami wiatru jasność i chłód-wiatru, co wzdyma się, przelata i zacicha - dzwonia skrzydłami o słońca struny nawiązane (Dum 145)

Żeromski, doskonały kolorysta ${ }^{9}$, nie mógł nie wprowadzać do opisu skrzydeł również barw, np.:

[Na przymorzu] Bieli się tylko $w$ dalekim błękicie stado mew wiecujacych. Złożone sa ich płowe, smużka biała ośnieżone skrzydła i białe głowy widnieja z dala na fali (Międz 297)

[do mewy] Czegóż ode mnie chcesz, skrzydlata, Com ci krzyw, śnieżnopióra? (Międz 297)

Jakże piękne [...] jest wówczas bezdenne morze. Nad czarnymi zwałami migaja białe skrzydła mew, dzioby i szpony ich padaja w grzebienie wodnych bryt, pisk przeszywa na wskroś burzę, a wąskie skrzydta wynoszą się naprzeciw piorunów (Róża 153)

Oczy [...] trafity na chyże rzuty płowych skrzydet śnieżnogłowej i wielkodziobej rybitwy, co się nad fala wznosiła i zniżała czatując na żarłocznego szczupaka (Wiatr 81)

W pewnym miejscu zerwała się kraska. Jej błękitne skrzydła migające między drzewami zbudzity na nowo myśliwskie instynkta Marcinka. Ale kraska była jeszcze przezorniejsza niż kaczki i znikła w gęstwinie bez śladu (Syz 125)

Złotem, lazurem i barwa zorzy wschodzacej pisane skrzydła motyla to się łacza ze soba, jak gdyby w lęku o kruchość tajni nadobnego pisma, to się rozwieraja bezczelnie przed słońcem, ni to obłąkana młodości żądza niebezpieczeństw (Dum 145)

Błękitne ważki na przezroczystych skrzydtach snuty się nad ta ruchoma, wiecznie żywa, nieustanna woda (Pow 68)

[...] poznikały nawet szklarze i modre świtezianki, wiecznie trzepoczace siateczkowatymi skrzydtami dokoła badylów sitowia (Zmierzch 55)

Dajcie odpowiedź, o wielobarwne skrzydła motyle (Dum 146)

[...] kręciły się jakieś wysoko postawione muchy ze złocistymi skrzydłami (Prom 114)

[autor obserwuje wędrówkę bożej krówki po liściach jagody] Ale czyż krówka nie widzi tych wielkich much o żółtych, złoconych skrzydłach, co pozasiadały wkoło listków (Dzien II 293)

2. 'jeden z dwu płatów nośnych przytwierdzonych z boku do kadłuba samolotu lub szybowca'

9 Zob. Kwiryna Handke, Świat barw, t. 5. serii Słownictwo pism Stefana Żeromskiego (Kraków: Universitas, 2002); taż, Polszczyzna Stefana Żeromskiego (Warszawa: Slawistyczny Ośrodek Wydawniczy 2012); taż, „Żeromski jako kolorysta”, Zeszyty Stowarzyszenia im. Stefana Żeromskiego 4 (2014), 11-29. 
Przysiadywat fałdów nad poszczególnymi badaniami techniki lotniczej [...] Mozolnie przerabiat tablice doświadczeń $i$ badań Langleya i Maxima z aerodynamiki [...] o wszelkiego rodzaju skrzydłach aerodynamicznych, o całej statyce i dynamice nowożytnego lotnictwa (Urod 176)

3. 'część ruchoma, ramię, śmigło obracające się, wirujące, stosowane w urządzeniach mechanicznych'

[Piotr podczas lotu płatowcem własnej konstrukcji] Podnióst się w górę jako kania. Dźwigną lotki prawego skrzydła i sprostowat aeroplan (Urod 384)

[płatowiec Piotra podczas lotu] Pochylnie płatowca stały się jako skrzydła wrośnięte w ramiona (Urod 382)

Nie przypadkiem właśnie w Urodzie życia znalazł się wątek budowy i lotu płatowca, skonstruowanego przez głównego bohatera. Żeromski interesował się aerodynamiką i konstrukcjami samolotowymi. „W historii samolotu Rozłuckiego wykorzystana została zapewne znajomość pisarza z inżynierem Witoldem Jarkowskim, profesorem aeronautyki w politechnice petersburskiej”"10. Nie jest wykluczone, że wpływ miały tu również osobiste wydarzenia z życia pisarza, który na początku XX wieku często przebywał na zachodzie Europy, a tam wtedy zaczęło się rozwijać lotnictwo, najpierw sportowe. W 1905 roku powstała w Paryżu Międzynarodowa Federacja Lotnictwa, rejestrująca rekordy lotnicze i zrzeszająca narodowe aerokluby. Powieść Uroda życia została wydana w 1912 roku, ale zamysł jej napisania powstał kilka lat wcześniej, o czym Żeromski pisał do żony Oktawii w listach z 26 lipca i 17 września 1909 roku (Listy, t. 37, s. 187 i 206).

4. 'boczna, wyodrębniona część budynku, zwykle ustawiona pod kątem do korpusu głównego'

Żeromski opisywał typową architekturę dworkową i pałacową swoich czasów, tym samym udokumentował jej istnienie. Jak wiadomo, z biegiem lat ten typ budownictwa zanikał, a wraz z nim i takie nazwy, np.:

Pałacyk składa się z dwu skrzydet parterowych, pośrodku których wznosi się piętro z duzym balkonem (Dzien II 323)

W pałacyku ,starszy pan” zajmowat jeden z pokojów prawego skrzydta (Char 239)

${ }^{10}$ Zob. Stefan Żeromski. Kalendarz życia i twórczości, oprac. Stanisław Kasztelowicz i Stanisław Eile (Kraków: Wydawnictwo Literackie, 1961), 297 - komentarz dotyczący, jak to określili redaktorzy, „wypadków autentycznych” w Urodzie życia. 
Zakończenie obydwu skrzydet starego ,pałacu” zamykały drewniane wieżyce (Char 235)

Pałac od strony ogrodu miat kształt podkowy. Dwa jego boczne skrzydla stały naprzeciwko siebie [...] Miejsce zawarte między skrzydtami i korpusem gmachu wypetnity kwietniki i gazony z egzotycznymi krzewami [...] Teresa z teściowa mieszkaty w lewym skrzydle pałacu (Wiatr 244)

Dwa skrzydta piętrowego domu (Char 79)

Żolnierz-wartownik wskazał im [...] drogę, która prowadziła między dwoma skrzydłami koszar wojskowych (Pop III 184)

5. 'jedna z części składowych większego przedmiotu, sprzętu, urządzenia, zwykle znajdująca się z boku, często ruchoma’

W obrębie tego znaczenia wyrazu skrzydło w tekstach Żeromskiego daje się wyróżnić kilka grup:

a) nakrycia głowy, które albo kojarzą się kształtem z ptasimi skrzydłami (SJPD zalicza je do przestarzałych), albo są przybrane skrzydłami

Kapelusz, czarujace borsalino, z dawniej nadanego mu kształtu artystycznego zawadiactwa przeszedt samowolnie w stan rozpaczliwej obwisłości skrzydet [...] W kapeluszu ze skrzydtami obwistymi (Pav 175)

[młody technik, pomocnik inżyniera] Głowe jego okrywat duży kapelusz z rondem w postaci skrzydet (Ludz 57)

Rondo kapelusza związanego pod broda oskrzydlało jej twarz (Pop II 69)

[Żydzi w warszawskim Ogrodzie Saskim] Kobiety miaty na sobie modne barwy. Caty ich ogrom mienit się od pąsowych i jaskrawoniebieskich staników, od fioletowych i czerwonych kapeluszów z ptasimi skrzydłami albo z kwiatami, które za każdym ruchem osoby kiwaty się nad jej głowa (Ludz 49)

[o zbójnikach, którzy w górach napadli Helenę i Rafała] Przypatrywat się [...] wysokim czapkom tych ludzi, do których jeden przyczepit sobie ogon lisa, drugi skrzydło wyrwane zabitemu orłowi, trzeci kty i paszczę niedźwiedzia [...] (Pop II 86)

b) poły płaszcza

[wolno idący szwadron konny] Wtem jak pistoletowy strzat rozlegt się głos komendy: - Za broń! Jak jedno machnęły prawe skrzydła płaszczów na ramię odrzuconych (Pop III 101)

[Ewa wspomina swój szary płaszczyk z czasów młodości w Warszawie] Mówiono jej o tym i pisano $w$ tajnych liścikach, że poły tego płaszczyka - to skrzydta anioła... (Dzieje I 197) 
c) części wiatraka

We mgle, kędyś daleko, wiatrak leniwie obracat swe skrzydła (Urod 288)

Fury naładowane grochem pędza szybko, aby umknać przed deszczem. Uciekam i ja, pozostawiając za soba machajacy na gwałt skrzydłami wiatrak (Dzien II 386)

Przyglądam się figurze pana S., gdy unosi się z fotela w całej swej ogromności i wyciaga prawice jak skrzydto wiatraka (Dzien III 322)

d) promień latarni morskiej

[na plaży w Royan] Olbrzymie skrzydło latarni, opisujące półkole o siedemdziesięciu kilometrach promienia, przeszukiwało otchłanie i samotnie morza (Zam 142)

Latarnie morskie poczęty miotać na nieskończoność wód skrzydła ogniste długie na kilkadziesiąt kilometrów (Urod 370)

e) kształt żagli pływających żaglówek

Trójkątne skrzydła ptóciennych żagli (Międz 300)

W przestworzu morza wędrowne, ostre skazy czerwonych żagli nad todziami, co niby uskrzydlone owady woraty się i zaczepity o równinę - a wnet odleca (Urod 383)

f) części sieci rybackich

[rybak] wyjechat $w$ wielkim bacie na morze, wyrzucit prawe skrzydło, macice, lewe skrzydto niewodu (Międz 358)

[rybacy] Każdy z braci wymiatał sieć swoją, złożona z matni i dwu krótkich skrzydet opatrzonych deskami, które stuża do rozpięcia niewodu. Do skrzydet i desek przywiazane mieli długie liny (Międz 352)

g) cechy kobiety

Coś niepospolitego, nakazującego bezwzględne postuszeństwo, władczego było w każdym uśmiechu, spojrzeniu, ruchu równych skrzydlatych brwi (Wszys 109/110)

[o Helenie] Gdy te oczy spod czarnych, skrzydlatych rzęs cisna spojrzenie, to jakby cię razity (Dzien II 448)

[o Helenie] Na moje szczęście graja mazura. Wraca jej wesołość, żywość, dowcip oczy ćmia się jak wtedy, gdy czaruje w salonie, staje się skrzydlata jakaś: życie jej, jej żywiot - zabawa - skrzydłem ją musnęła (Dzien II 36)

Miała włosy czarne jak skrzydła kruka (Cien 284) 
[opis spotkanej dziewczyny] [...] szczególnie wspaniate i szczególnie nieprzyjemne sa te brwi: co chwila drgaja one porywczo, zuchwale, dumnie, jak waskie skrzydła ponurego ptaka (Dzien II 437)

[doktor Obarecki wspomina „Siłaczkę"] Ona nie podniesie oczu, zmarszczy brwi, podobne do prostych a waskich skrzydełek jakiegoś ptaka (Sił 99)

[...] tęsknity [...] oczy do jej oczu, do dwu czarnych aniołów, ostonionych subtelnościq cieniów niby dwojgiem plochliwych skrzydet (Urod 84)

h) warto też wymienić i taką dwoistość:

My, kajdaniarze, wiemy... Walka dla zniszczenia ucisku - to dopiero jedno skrzydto. Bo drugie skrzydto - to praca (Urod 345)

6. 'ugrupowanie wewnątrz jakiejś partii, stronnictwa, organizacji, różniących się poglądami od reszty członków; odłam’

[wśród uczniów w szkole w zaborze rosyjskim] [...] którzy stanowili najbardziej prawe skrzydto tej prawicy (Syz 220)

Militarna tematyka utworów Żeromskiego decydowała o wprowadzeniu do ich tekstu określonego nazewnictwa, związanego z uzbrojeniem wojsk różnych okresów historycznych. Stąd częste skrzydła w znakach husarii, stąd też nazwy ugrupowań i szyków bojowych wojsk. Warto dodać, że Żeromski miał bardzo dużą wiedzę w dziedzinie wojskowości ${ }^{11}$.

8. hist. 'element składowy zbroi husarskiej w postaci wielkiej blachy w kształcie skrzydeł ptasich lub ramy z wprawionymi w nią piórami, najczęściej orłów lub sępów’

[...] jakoby ów podjazd szalony Odrzywolskiego Jana, co pocwałowat orloszumiacy skrzydlami w paszczękę nieprzyjacielska (Dum 116)

[...] między sępie skrzydta, kity i czuby ich wodzów, między polyski jataganów [...] (Dum 124)

[...] a nieskazitelnym pióropuszem zaramiennych skrzydet, co stawę żotnierzom szumiaty, zamiata piach niskiego dna (Dum 128)

Hetmański na czele znak, drzewo z wprawionym w nie skrzydtem rozpostartym, orłowym (Dum 117)

${ }^{11}$ Zob. Ryszard Handke, Walka, wojna, wojskowość, t. 6. serii Stownictwo pism Stefana Żeromskiego (Kraków: Universitas, 2002). 
[rycerze] Zaramienne skrzydta w kunsztownej oprawie zrosty się w las, w puszczę młoda, po której strzelistych piórach sława szeleszcze (Dum 117)

A skoro poszli skrzydlaci w petny cwat, we wszystek choragwiany pęd-nie strzymata Moskwa razu (Dum 180)

11. wojsk. a) 'boczna część ogólnego ugrupowania bojowego; w mustrze: prawe lub lewe zakończenie szyku'

Skrzydło stojące na brzegu od strony Alp Berneńskich rzuciło się w bród i prawie po szyję zanurzywszy się w wodzie wyszło na brzeg w sile kilku setek ludzi (O żoł 240)

W prawym szyku Herman Denhof jak strzała wbił się w skrzydła janczarskie (Dum 113)

Stanisław Koniecpolski, hetman polny, czyni w obozie rząd dzienny i dysponuje szyk w polu. On ma pod soba skrzydło prawe. Na czele wszystkiej sity skrzydła lewego trzyma dowództwa buzdygan Samuel książe Koreckie, Pogoń odwieczna na tarczy noszacy (Dum 113)

Sformowana przez Dunina piechota uderzyła z dwu skrzydet, od jeziorzysk i lasów (Wiatr 178)

[kampania Napoleońska, rok 1799] Baron Kray złamał już byt lewe skrzydło armii Scherera [...] Batalion polski (pierwszy) pod szefem Dembowskim zastaniał cofanie się prawego skrzydta ku Vigaccio, a generat-adiutant Kosiński ostaniał lewe skrzydło na drodze ku Nogara (Pop I 259/260)

Kompania miała rozkaz przebyć błota rzeczki Rawki poniżej trzech stawów w Michałowicach i od pierwszego skrzydła, z miejsca, gdzie stała ostatnia wedeta, wejść w lasy (Pop III 120)

Ze zbioru znaczeń wyrazu skrzydło, jakie znalazły się w SJPD, w tekstach Żeromskiego brak trzech: 7. geol. 'część boczna skalnego siodła lub łęku’; 9. sport. 'boczna część boiska'; 10. spoż. 'mięso wołowe, część przy zrazowej'.

Natomiast jest u Żeromskiego poświadczenie znaczenia ptasich skrzydeł jako ochrony, opieki, utrwalone zarówno w funkcji podstawowej, jak i metaforycznej, a nawiązujące do utrwalonego od czasów biblijnych (brak w SJPD):

[...] gdy deszcz spada na urocze zarośla, słowiki zanosza się od śpiewu. Może kapiąc się w tym dżḋu doznaja rozkoszy, może on zaspokaja ich pragnienie, a może dokucza samicom, które szczelnie skrzydłami otulaja gniazda (Mog 84)

[...] gdy dosięgnąt pewnej myśli podspodniej, bezsilnej jak pisklątko pod matki skrzydtami (Wiatr 75) 
[...] wszystkie trzy dziewice odruchowo zbliżyly się do starej damy, jakby się przed zbójca chronity pod jej skrzydła (Ludz 15)

\section{Metafory}

W zbiorze związków wyrazowych o charakterze frazeologicznym i metaforycznym można wyróżnić kilka grup, z podkreśleniem, że konteksty Żeromskiego nierzadko łączą w sobie cechy wyrażeń i zwrotów.

a) Wśród wyrażeń niektóre kojarzą z kształtem skrzydeł wygląd różnych elementów otaczającego świata, np.: wody, lasu, mgły, sadzy itp.

[Mantua, rok 1799] Wtem runą gromem strzat armatni. Okna zadrżały w swych zawiasach wszystkimi futrynami [...] W luftach kominów załopotały stracone skrzydła sadzy (Pop I 265/266)

Parowiec wydobyt się zwolna z portu, wyszedt na petne morze... Pomkną w kierunku wyspy Capri, ciagnac za soba smuge białego dymu i dwa szerokie skrzydła na morskiej równinie... (Dzieje II 23)

Statek nurzajac się $w$ toń wstrząsat jej uśpiona powierzchnię i ciagną za soba jakby obwisłe skrzydła z fal rozpostartych (Na pok 201)

Dwa wielkie skrzydła tego przedwiecznego Wisty tożyska nieznane sa, albowiem w morzu na zawsze zginęty (Międz 307)

[w górach] $W$ górze, na zrębach podobnych do piór skrzydta pancernego rycerza, chwiaty się odwieczne kępy świerków i zwisat rudy mech (Pop II 84)

Z obu stron drogi zbliżały się coraz bardziej ku jadącym skrzydła rozległe szerokiego lasu (Pop II 133)

[Helena i Rafał w drodze w góry] Wtem droga zawisła nad urwiskiem i skręciła się $w$ miejscu. Las uciekt sprzed oczu i, jakoby ciemne skrzydto, chyżo poleciat w bok, na dót (Pop II 72)

Błonia obroste wiklina, daleka przestrzeń tamtego, prawego brzegu z jego miasteczkami, smugami wsi i skrzydłami lasów ukazywaty się niekiedy jak odbicia chmur (Pop I 67/68)

[staw w Wygnance o świcie] [...] woda samotna została $w$ dole, a mgly porzucały jej łono. Zwijały swe cudne, powłóczyste szaty, rozszerzały przezroczyste skrzydła i mdlejacc, wijac się z żalu, ginęty $w$ błękicie (Pop I 144)

Wysoko stały białe obłoki jakby zaspy śniegów spiętrzonych, pomalowane ślicznymi cieniami. W głębi ich skrzydet rozlegat się istny chór skowronków (Ludz 109) 
Onego wieczora świecił księżyc. Chmury skrzydlate leciały z zachodu na wschód przed nieruchoma światłościa tarczy (Dzieje I 214)

[Ewa na ulicy] Dała się ciągnąć tłumowi, jakiemuś skrzydłu wielkiego włoku ludzkiego (Dzieje I 110)

b) Niekiedy skrzydło staje się synonimem ptaka

[wyobrażenia Judyma na dole w kopalni, gdy myśli o tym, jak ona powstawała] Te wielkie potwory, splecione między soba łańcuchami lian, krzewity się na pulchnym torfowisku [...] Stodkie upalne lata wyciagały z ziemi pod chmury te pnie i gatęzie, dostepne tylko dla wzroku i skrzydet; wilgotne, deszczowe zimy zasilaty glebę na wieku (Ludz 324)

c) Raz po raz spotyka się przywołania skrzydeł anielskich oraz ich przeciwieństwa skrzydeł szatana, których synonimem są: czerń, ciemność i upadek

[Ewa w Nicei, obserwująca błyski latarni morskiej] Bo tam był anioł groźny nad niezgruntowanymi wodami... Skrzydła jego od zachodu na wschód... (Dzieje I 276)

Pchnięte skrzydłem anielskim pociagnęty głuche wody na wschód - na zachód (Wis 9)

[Bodzanta do Ewy] [...] mam taka polska manię, żeby wyzwalać anioła. Lubię patrzeć, gdy mu rosna skrzydta [...] Może skrzydła którego z nich, gdy popłynie ku niebu, zaniosa daleko grzeszna moja modlitwę za Martę! (Dzieje II 169)

Nagle przelatuje jedna myśl jak błyskawica: sprzedać pierścionek otrzymany od Heli. Zdaje się, że ta myśl nie wylęgła się w mózgu, ale jest nad toba w powietrzu, wisi jak szatan, otacza się czarnymi skrzydłami marzeń o zaspokojeniu głodu-a jednocześnie wbija w serce pazur (Dzien III 84)

[Jan z Kolna] Huczały mu nad czolem czarne skrzydła zmowy (Wiatr 192)

[rozmyślania Ewy w kościele] Zapytana w owej chwili, odpowiedziałaby bez wahania, że to szatan szkarłatnymi skrzydłami okryt jej duszę (Dzieje I 78)

[stan Ewy, która wie, że jest w ciąży] Smagały ja zjadliwe a milczące spojrzenia. Trzepały się nad nią czarne skrzydła słów plugawej zniewagi (Dzieje I 192)

Tam oto marzenia bezwiedne bratają się z pożądaniem, tam niezgłębiona miłość przytula się do prośby - i stoi zawieszona w przestrzeni pod czarnymi skrzydłami świadomej, a przecież bolesnej zdrady (Dzien III 65)

Myśl się wzniosła nad nizina opuszczona jak gdyby anioł wszystko widzacy. Lecz nagle wicher nieubłagany uderzyt w jej skrzydła, wytamat je ku dołowi, zwichnąt i potargat (Wszys 114) 
Zdawało mi się, że ciemność nie tylko mnie otacza, ale idzie przeze mnie na wskroś, jak idzie przez wodę. Miękkimi, niewidzialnymi piórami swych skrzydeł dotykała każdej myśli i gasiła iskierki pociechy (Mog 103)

d) Bardzo liczne są skojarzenia z wiatrem, także z zamiecią, co potwierdza trwałość odwiecznego określenia na skrzydłach wiatru (zob. wyżej). U Żeromskiego nie są to jednak tylko proste cytaty, choć są i takie, ale obok nich więcej kontekstów stanowi rozmaite przetworzenia pierwotnego zwrotu przez użycie innych czasowników niż lecieć, wyrażające nie tylko latanie, ale i inne ewolucje ptasich skrzydeł, np.:

Aż o wyśnionym północku, gdy zamieć bije skrzydłami o czuby zamczyska (Pow 88)

Potem i wiatr zwiną skrzydła, i zawist w przestrzeni pachnacej zywica, wiklina i zbożami (Pok 79)

Polotny wiatr wywiewa z niego i zabiera na błogostawione swe skrzydła nieprzezwyciężoną noc udręczenia (Wis 8)

[park w Grudnie] Drzewa nad tym ciennikiem i w głębi parku, z dala stojace głuchym, dumnym, uprzywilejowanym zastępem, zdawaty się nie rosnać, nie wznosić, nie dźwigać z tej ziemi, lecz na skrzydłach lecieć ku niebu (Pop I 174)

Bardzo dawne i niewymownie miłe mary zlatywaty ku niemu na skrzydtach powiewów wiosennych (Syz 41)

Kiedy niekiedy ciepły wiatr nióst tu na skrzydłach swoich odgłos szelestny młodego zboża (Ludz 196)

Wiatr-herold świtu lata nad światem głoszac kwiatom, ziołom, drzewom i ptakom: słońce! Sa chwile, że $i$ wiatr zwija skrzydta i wisi niemy w przestrzeni [...] Cisza jest wtedy nieopisana (Dzien II 279)

Ogromna, niebieska, o miedzianym odbłysku chmura zbliża się na skrzydłach wiatru (Dzien III 113)

[...] wyższe obłoki wirowały i niosty się w przestwór na skrzydłach wiatru (Urod 384)

Chata [...] Nawat wichrów siekt ją i prat, podważat liche jej przyciesi [...] pędził dokoła kwiczac przeciagle, thukt w nia stumilowymi skrzydtami $i$ wszczepiał między belki żelazne swe pazury (Pop I 116)

[Cezary w sianie na polu, po bijatyce w Leńcu] Przelotny wiatr stat się dlań dobry i czuły [...] Na skrzydła swoje brat jego czucie zranione i nióst je dokadś (Przed 246)

Zza drzew ogrodu zaczęła się wychylać straszna ogromem, ziejąca zimnem, lecaca na skrzydłach wichru - hiena-chmura (Dzien II 352) 
e) Najliczniejsze są konteksty zawierające wyrażenia i zwroty przedstawiające rozmaite stany, myśli, odczucia, emocje, takie jak: dowcip, fantazja, geniusz, marzenie, szczęście, pewność siebie, postanowienie, złudzenie, nieszczęście, pośmiewisko, rozpacz, zniewaga itp., a nawet czas, a także myśl, muzyka, poezja, pieśń, praca; skrzydlata jest też miłość, skrzydlate są słowa, wyrazy itp. Wszystkie one „dostają skrzydeł”. Warto przy tym zauważyć, że prawie połowa takich kontekstów pochodzi z Dzienników, które młody Żeromski traktował jako rozmowę z samym sobą i powierzał im swoje osobiste myśli, opinie, spostrzeżenia, wrażenia oraz emocje, np.:

[pani Sabina Topolewska w Posusze] [...] gdy się patrzyło z boku na tę osobę już czterdziestoletnia, jak z wdziękiem podlotka, na skrzydtach dowcipu $i$ wesela przefruwała z kwiatka na kwiatek (Naw 153)

[o lekturach, zwłaszcza o książkach Brandesa] Książki te wyrobiły we mnie niejaki artyzm, przyprawiły skrzydła fantazji (Dzien I 297)

W cieniu ich szaty książęcej geniusz ludu włoskiego rozwijał skrzydła (Suł 74)

[Jasiołd o swoim zakochaniu] [...] kotysat się na skrzydtach szczęścia (Char 249)

[Jaz, bal w dniu św. Szczepana] Właśnie kapela zagrała polskiego i wynioste, wspaniałe dźwięki porwały na skrzydła swoje nowe postanowienie Rafała (Pop II 228)

[autor po posiłku, który przyszedł po długim głodowaniu] Czuję chęć do pracy i unoszę się na skrzydłach bezwiednej, odruchowej, pozbawionej podstawy pewności siebie (Dzien III 87)

[Rafał ranny po walce z wilkiem] Głowa stała się głazem lecacym w przepaść jakby w ciasna, ognista studnię. Płochliwe skrzydło złudzenia kurczyło się co minuta (Pop I 117)

[Ewa, gdy domyśla się, że jest w ciąży] Widziała wtedy wzrokiem użyczonym, podczas gdy włosy jeżyły się na głowie, a w uszach syczat świst i łopot tajemniczych skrzydet nieszczęścia, wszechmoc namiętności (Dzieje I 190)

Domyst nie otamowany rachunkiem, zakazany samemu sobie bez zamknięcia go w ścisłe koło dowodów, leciał na skrzydłach rozpaczy (Wiatr 203)

Muzyka to najlepsza towarzyszka i opiekunka nasza. Bez niej myśl nie miałaby skrzy$\operatorname{det}$ (Dzien I 291)

[Nienaski] Na skrzydtach tej muzyki przemierzat jak gdyby po wtóre, jak gdyby przy blasku słońca wszystko, co $w$ duszy zdarzyło się $w$ nocy, $w$ ciemności, $w$ niewiedzy (Naw 202)

Bytem na koncercie hiszpańskim [...] Grano, grano... serenadę Szuberta. Tej pieśni, nieśmiertelnie pięknej, dość do wypędzenia szatanów [...] przenosi duszę na skrzydłach muzyki w kraj, gdzie szatanom wchodzić nie wolno (Dzien I 270) 
Dziś staliśmy z Tomkiem pod jego oknami i stuchali czardasza [...] Doprawdy leciałem na skrzydtach tej pięknej węgierskiej pieśni. Czardasz jest ulubionym tańcem moim (Dzien I 267)

[...] jeden duch unoszacy mię niekiedy w błogosławione szczęścia krainy na skrzydłach poezji (Dzien I 49)

[...] genialny pomyst - to wyrywanie się człowieka z piasków i iłów ziemi ku słońcu na skrzydłach pieśni (Suł 177)

Przyprawcie pracy organicznej skrzydła, którymi niech leci do niepodległości (Dzien II 410)

[ranny Cedro] Dech zapiera. Serce się zrywa i łomoce skrzydłami w gałęzie niby złapany siecia dziki orzel-zyz (Pop III 106)

Czas leciał na skrzydłach, a dzień zwłoki o wszystkim stanowit (Pop II 267)

U boku broni żadnej. Na głowie szyszak pogardy. Zza ramion skrzydła pośmiewiska szeleszcza (Pow 93)

[katedra w Mediolanie] Jestem tu trzeci raz w życiu. Zawsze inne uczucie. Muzyka, chór za ołtarzem. Bóg katolicyzmu zwiesit swe skrzydła olbrzymie (Zapis 152)

Jam poeta, a mnie skrzydet przypiąć nie dają sobie, a mnie każa gnić w błocie. Precz z ludźmi, mam moją wolę, jam pan sobie! Dosyć już długo giątem kark. Chcę polecieć i latać, latać, póki skrzydet wystarczy. Choćby potem jak Ikar upaść (Dzien I 238)

Tacyż to sa kapłani sztuki! [...] Stał wysoko, chciat wzlecieć jeszcze wyżej... Lecz lot bez skrzydet sprowadza zawsze upadek, a lot z cudzymi skrzydłami musi rzucić w błoto poniżenia wcześniej czy później (Dzien I 233)

[...] tyle razy na dzień lecę do Ciebie na dziwnie szybkich i dziwnie szerokich skrzydłach, że nie powinnaś o mnie watpić (List do Oktawii Rodkiewiczowej z 12 II 1892 r., Listy I, s. 133)

[...] ty, Chryste biednego życia [...] - ty nas wynosisz na skrzydtach i zakrywajac nimi zgniliznę padołu, wskazujesz błękit niebios (Dzien III 69)

[Bukowicz o sobie do Zofii] Więc o tym ptaku... o cudnym ptaku. Musimy o nim prędko mówić, gdyż zaraz rozwijam skrzydła i lecę do panny Anny (Grzech 47)

[Jasiołd po rozmowie z Granowskim, który go namawiał, żeby się zaopiekował Śnicową] Można by bronić ją i wspierać. Zdawało się młokosowi, że mu u ramion skrzydta urosty (Char 220)

Przecie ten, kto chce latać na skrzydtach, musi się wywyższyć ponad tych, co chca tylko petzać, i to na kolanach (Urod 213)

Czuł w sobie lekkość i zdolność do lotu jak ptaki. Rozłożyć tylko skrzydła i uciec z ziemi (Pav 203) 
W wyobraźni dziecięcej ukazat się oficer [...] biegnacy [...] z obnażona szabla [...] Zdało się dziecku, że mu nad głowa skrzydła szumia... (Wszys 131)

[...] miłość skrzydlata, która znów przyleci nieproszona (Dzien I 386)

[...] jak $w$ duszy sepie twoje spojrzenie i twe skrzydlate, dziejowe słowo pod sercem chowat (Dum 178)

[profesor na stancji, gdy Rafał i Krzysztof, nadzy i ubrudzeni po przygodzie na Wiśle, wrócili do domu] Wreszcie słowo skrzydlate wyfrunęło z jego tacińskiej gardzieli: Olbromski!... to ty, ptaszku! Twoja to jest nowa sprawka... (Pop I 77)

[Judym o Joasi] Judym przez chwilę daremnie czekat, że usta powiedza wyraz skrzydlaty, który chowat się w tym prześlicznym uśmiechu (Ludz 278)

\section{Porównania}

O porównaniach występujących w tekstach Żeromskiego a odnoszących się do relacji człowiek-świat zwierząt pisałam w artykule zamieszczonym w 15. tomie „Studiów Językoznawczych"12. Tam znalazło się m.in. osiem kontekstów zawierających wyraz skrzydło. Tutaj omawiam, w innym ujęciu, pełny i nie tak jednorodny zbiór porównań ze składnikiem skrzydło (a w ilustracji materiałowej dotyczącej człowieka powtarzam tylko niektóre konteksty spośród wymienionych poprzednio).

U Żeromskiego porównania rzadko bywają proste, zazwyczaj stanowią rozbudowane konstrukcje (nazywam je kontekstami fabularnymi), a semantyczne związki stron porównania oparte są na różnych zasadach doboru cech.

W tym zbiorze mamy kilka podmiotów, które porównywane są ze skrzydłami: głównie ptaków (w tym również konkretnych ptaków: bekasa, jaskółki, jastrzębia, kwiczoła), wyjątkowo też ze skrzydłami nietoperza, ale również ze skrzydłami anioła, szatana i wiatru. Wśród podmiotów mamy: ludzi, zwierzęta, obiekty przyrody oraz podmioty niematerialne (abstracta): czas, dusza, nadzieja, pieśń, ślad przeszłości, pamięć, tęsknota, troska.

a) Ludzie są porównywani do ptaków, a skrzydła są dla nich siłą wyzwalającą albo przeciwnie - niszczącą

Czuł w sobie lekkość i zdolność do lotu jak ptaki. Rozłożyć tylko skrzydła i uciec z ziemi (Pav 203)

Bytem bowiem największym (bo jedynym) na całe Świętokrzyskie Góry poeta udajacym myśliwca i rybaka. Miałem w sobie lekkość lisa, nogi jelenia i jak gdyby skrzydta bekasa u ramion. Pisałem swe marne wiersze w lasach i na wertepach (Pusz 267)

12 Kwiryna Handke, „Relacje: człowiek - świat zwierząt w porównaniach występujących w tekstach Stefana Żeromskiego”, Studia Językoznawcze. Synchroniczne i diachroniczne aspekty badań polszczyzny 15 (2016): 5-18. 
[17-letni Antoś, śpiewający w podskokach] Te rozmaite śpiewanki zdawały się nosić go po świecie jak skrzydła nosza ptaka (Złe spoj 161)

Wszystko powietrze było tak przeczyste, tak ciche, takjakoś lotne, że zdawało się, jakoby człowiek byt ptakiem... Rozłożyć skrzydła w lodowatej przestrzeni i uchodzić w górę z tej ziemi! (Naw 284)

Począt chodzić po miękkim dywanie [...] - począt przesuwać się wzdłuż mebli, jak gdyby fruwat na niewidzialnych skrzydłach (Pav 207)

[Smętek] Ruch jego każdy byt celowo nieomylny, jako rzut skrzydła jastrzębia, rylcem doskonałości we wklęstych cyrklowany niebiosach (Wiatr 61)

[osłabiona matka Cezarego] Lecz siły tej kobiety malały. [...] W oczach latat jakby rój skrzydeł czarnych nietoperzów (Przed 36)

[Anzelm] Uczułem jak gdyby skrzydła drapieżnego kondora wrośnięte w moje ramiona (Róża 19)

[Piotr] Serce ściskato się w nim i dusza zamierała [...] gdy się tlukt jak ptak z wykręconymi skrzydłami, nagle złapany z wolnego powietrza miłości i z przestworów szczęścia w ciemność zdradzieckiego potrzasku (Urod 110)

[chory] [...] idzie przez mus, przez wysiłek, jak ślimak, choć się zrywa w nim coś jak $k$ wiczol zaczepiony noga $w$ sidle, choć trzepoca $w$ nim niby skrzydta ptasie. I nie może podlecieć wyżej jak na dtugość sidła i ciagle spada, a spada... (Cokol 44)

[Jasiołd we śnie myślący o Celinie Śnicowej] Senne cierpienie wzniosło się jako burza [...] Nogi same biegna po schodach kamiennych śpiącego domu, serce jest jako ptak skrzydlaty, któremu huragan kości skrzydet połamat (Char 199)

b) Zwierzęta poruszają się jak ptaki lub wiatr

[klacz Baśka w ucieczce przed wilkami] Gdy do jej uszu doleciał ostuch wilczego cmokania, gnała znowu ze zdwojona siła, śmigała jak ptak, skrzydła orle majacy u każej pęciny, brzuchem rozgarniała śnieg na ziemi (Pop I 110)

[Rafał i Michcik uciekają z Tarnin przed Austriakami] Leca jak ów ranny wicher na skrzydłach wiatronogich koni, ścigani dalekim krzykiem austriackim... (Pop III 244)

c) Anioł skrzydlaty symbolizuje dobro, opiekę, pomoc, wybawienie

[Salomea i matka przy rannym Odrowążu] Gdy chory zakaszlał albo jęknąt, biegty jak dwa skrzydła tego samego anioła osłaniać go, chłodzić czoło, pocieszać (Wier 135)

[Piotr w Krakowie słucha hejnału] Błogosławiona pieśń nie ustawała. Jakoby skrzydła silnego anioła podłożyła się pod czujną a strudzona duszę (Urod 314)

[...] skostniatym zamroczeniom rozpaczy, gdy dobrotliwa władza pamięci jak aniot zastania skrzydlami rzeczywistość (W sid 135) 
Na zachodzie mgiełka niebieskawa ptynęła przez niebo zorzane, jak zadumany anioł, co opuściwszy skrzydła znużone od lotu pracowitego, kieruje się ku krańcom świata (Dzieje I 170)

[Capri, morze] Brylantowe iskry sypia się po powierzchni. Chwilami rozpościera się coś, jakby srebrzyste skrzydła olbrzymiego anioła, który przez morze idzie (Zapis 162)

Stała się lekka, jakby ja wielkie skrzydła anioła niosty nad ziemia (Sen o chl 77)

$W$ przestworze zalanym świattem miesięcznym stały tu i owdzie na niebie rozwiane blade chmurki niby skrzydła i szaty cherubinów (Prom 119)

[Rafał w górach po śmierci Heleny] Rzucit w kamienny świat krzyk z całej piersi. Na wschód, na zachód, na pótnoc i na południe... Głos nieszczęśliwy leciał w ciemne doły, w błękitne przepaście, jak anioł z wątlymi skrzydty, rozbijał się na krawędziach, roztrzaskiwat o strome gzymsy i skonat w tożyskach otchłani (Pop II 95)

d) Szatan symbolizuje zło, kojarzy się z ciemnością

Ciemność parna i duszna latała nad ziemia niby skrzydła szatańskie (Arym 22)

e) Obiekty otaczającej przyrody (wiatr, łachmany śniegu w górach, dymy, gradowe obłoki)

Lekkie obłoczki suna nad głowa, zrywa się co chwila wiatr $i$, niby skrzydła ptaka-olbrzyma, bije w gatęzie wiklin (Dzien III 392)

[Rafał i Helena w górach] [...] stały poszczerbione turnie. W mroku ich złomów wisiały czarne łachmany śniegu o barwie trupiej kości, która wicher, słońce i deszcz w próchno obracają. Czaity się tam jak olbrzymie, białawe nietoperze z rozciagniętymi skrzydtami (Pop II 78)

[podpalane przez Prusaków gdańskie przedmieścia] Dymy rozpościerały się lub składały niby skrzydła olbrzymie, już to zapraszając obludnie, pociagając zdradziecko, już zamykając widok na zawsze w ciemnicy śmierci wiecznej (Wiatr 218)

[...]jako skrzydła obłoków gradowych, poczna się rozciagać, rozwłóczyć, wytężać nieprzyjaciela zagony (Dum 214)

f) Podmioty niematerialne (abstracta)

[autor odwiedza Kielce po latach] Dusza ucieka w minione lata i waży się jak ptak na skrzydłach wspomnień (Dzien III 48)

Sa to figle tęsknoty, jaka trzepie się $w$ sercu na podobieństwo ptaka ze zwiąanymi skrzydtami (List do Oktawii Rodkiewiczowej z 6 VI 1892 r., Listy 34, s. 334) 
[...] po podniesieniu zaczynali całym kościolem śpiewać swoja pieśn - „Święty Boże, Święty Mocny, Święty a Nieśmiertelny" [...] Nieuczony, potężny, jednolity głos thumu podrywat się z ziemi jak ptak, rozpościerat skrzydta i szybowat ku niebu (Urod 287)

[gruzy Tyńca] [...] patrza w otchlań zamartych czasów, niedocieczona dla nikogo na ziemi, w zdarzenia z których powstat taki jedynie ślad jak ślad jastrzębia, który w powietrzu przepłynąt, śniady na ziemię rzucit cień rozpostartych skrzydet i odlecial (Wis 19)

A ponad tymi słowy, jak czarne motyle, a może jak btękitne, przejrzystoskrzydte tatew$k i$, snuly się troski i nadzieje (Dzieje I 132)

[marzenie Rafała o Elżbiecie] Była także zachwycająca nadzieja, która wiedzie jakoby na skrzydtach motylich poprzez czas i przestrzeń (Pop II 221)

Niepostrzeżenie niby na skrzydłach jaskótki przeleciał czas poludniowy (Wszys 135)

[Rafał w Tarninach na pokucie] Byty dni, że czas leciat jak jaskótka na skrzydtach (Pop I 90)

Ostatnie dni zeszly szybko, przelecialy jak na ptasich skrzydlach (Urod 122)

\section{Kilka słów na zakończenie}

Pisarz poprzez teksty przekazuje niektóre cechy swojej osobowości, zostawia w nich ślady swoich życiowych przeżyć i nabytych doświadczeń. Dlatego podczas badania tworzywa językowego tekstów pisarza, zwłaszcza przy analizowaniu zawartego w nich słownictwa, warto raz po raz zadawać sobie pytanie: dlaczego? A w interpretacjach poszukiwać na nie odpowiedzi - również w biografii autora.

W powyższym przedstawieniu tematu starałam się na przykładzie wybranego fragmentu słownictwa z tekstów Żeromskiego dojrzeć i uwypuklić niektóre istotne wydarzenia z życia pisarza.

Co do samego przedmiotu analizy materiałowej, widać, że wyraz skrzydło/skrzydła był dla Żeromskiego bardzo przydatny w opisach świata rzeczywistego i przedstawionego. $Z$ jednej strony dzięki doskonałej obserwacji znał świat latających stworzeń i umiał go przedstawiać, znał również doskonale język polski, którym ten świat opisywał i wyrażał. $\mathrm{Z}$ drugiej strony tkwił głęboko w śródziemnomorskiej tradycji kulturowej i odczuwał odwieczną jej symbolikę, która pozwoliła mu budować tak wiele kontekstów o charakterze metaforycznym.

W konkretnej tekstowej realizacji Żeromski wydobywał i uwypuklał niezwykłość skrzydeł nie tylko jako doskonałego narzędzia latania, poruszania się ponad ziemią, dokonywania najrozmaitszych ewolucji, a przede wszystkim pozbywania się więzów i odczuwania wolności. Akcentował ich niezwykłość dzięki treści, jakie niosą w sobie, ponieważ są wieloznaczne leksykalnie i symboliczne pojęciowo. 


\section{Skróty tytułów utworów, z których pochodzą cytaty}

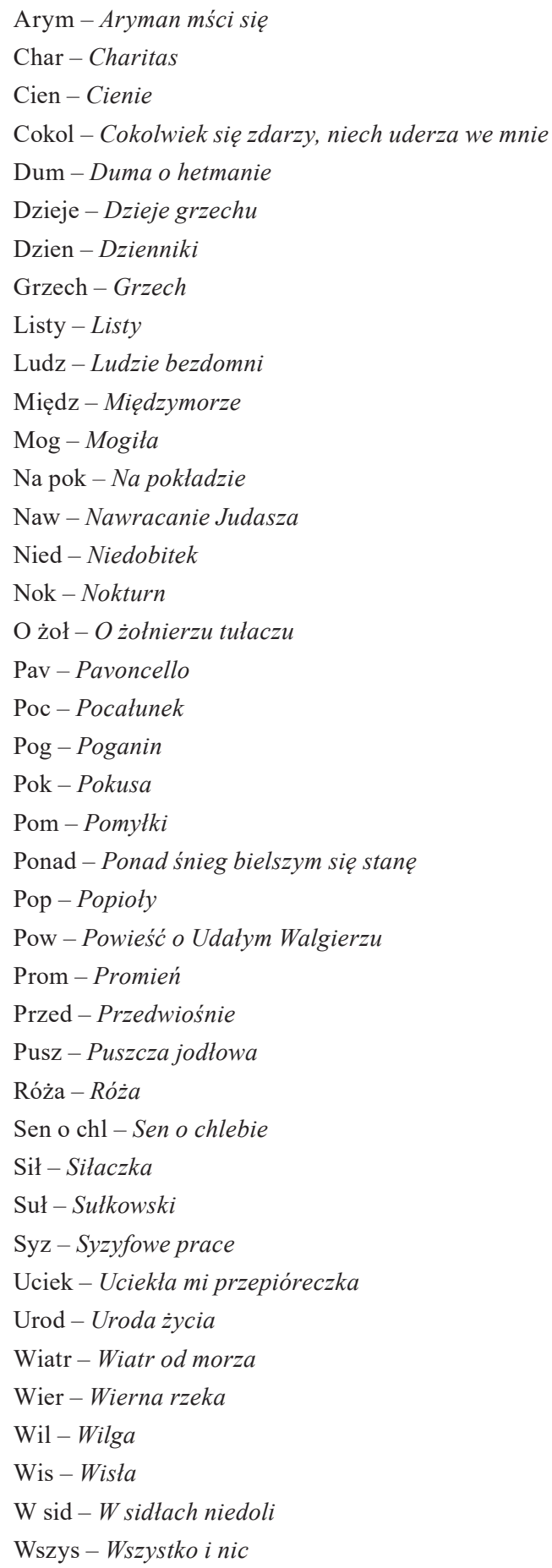


Zam-Zamieć

Zap - Zapomnienie

Zapis - Zapiski z podróży

Złe spoj-Złe spojrzenie

Zmierzch - Zmierzch

\section{Bibliografia}

Bartnicka, Barbara. Świat dźwięków. T. 4. serii Słownictwo pism Stefana Żeromskiego. Kraków: Universitas, 2003.

Doroszewski, Witold, red. Stownik języka polskiego. T. I-XI. Warszawa: PWN, 1958-1969.

Handke, Kwiryna. ,Relacje: człowiek - świat zwierząt w porównaniach występujących w tekstach Stefana Żeromskiego". Studia Językoznawcze. Synchroniczne i diachroniczne aspekty badań polszczyzny 15 (2016): 5-18.

Handke, Kwiryna. Świat barw. T. 5. serii Stownictwo pism Stefana Żeromskiego. Kraków: Universitas, 2003.

Handke, Kwiryna. Polszczyzna Stefana Żeromskiego. Warszawa: Slawistyczny Ośrodek Wydawniczy, 2012.

Handke, Kwiryna. „Żeromski jako kolorysta”. Zeszyty Stowarzyszenia im. Stefana Żeromskiego 4 (2014): $11-29$.

Handke, Ryszard. Walka, wojna, wojskowość. T. 6. serii Stownictwo pism Stefana Żeromskiego. Kraków: Universitas, 2003.

Kasztelowicz, Stanisław, Stanisław Eile, oprac. Żeromski Stefan. Kalendarz życia i twórczości. Kraków: Wydawnictwo Literackie, 1961.

Kopaliński, Władysław. Stownik symboli. Warszawa: Wiedza Powszechna, 1990.

Skorupka, Stanisław. Stownik frazeologiczny języka polskiego. T. I-II. Warszawa: Wiedza Powszechna, 1989.

Żeromski, Stefan. Dzienniki. T. I-III. Warszawa: Czytelnik, 1953-1956.

Żeromski, Stefan. Listy. Oprac. Zdzisław J. Adamczyk. W: tenże, Pisma zebrane. T. 34-39. Warszawa: Czytelnik, 2001-2010.

Żeromski, Stefan. Pisma, red. Stanisław Pigoń. Warszawa: Czytelnik, 1947-1956.

Skrzydła - wyraz i nośnik symboli w tekstach Stefana Żeromskiego

Streszczenie

Tworzywo językowe zawarte w tekstach literatury pięknej może być, i bywa, rozmaicie postrzegane przez badaczy. Językoznawcy najczęściej zwracają uwagę na elementy słownikowe, specyficzne nazewnictwo czy określone formy gramatyczne lub słowotwórcze, a także na tekstową funkcjonalność poszczególnych leksemów czy form lub ich grup albo zbiorów tematycznych. Niektórzy śledzą również tropy stylistyczne, zwłaszcza metafory i porównania. Rzadziej spotykamy analizy wykraczające swoim zasięgiem poza tekst literacki jako płaszczyznę penetracji badawczej, czyli poza relację: tekst-badacz. Tymczasem ujęcie szersze, w którym uwzględni 
się trójstronną relację: pisarz-tekst-badacz, pozwala dostrzec więcej aspektów niemal każdego badanego zagadnienia czy tematu. Przy tym pisarza należy tu postrzegać nie tylko jako autora, kreatora tekstu, nadawcę komunikatu, twórcę oryginalnego warsztatu pisarskiego, ale również jako jednostkę ludzką, egzystującą w określonym czasie i miejscu/miejscach, osobowość o określonej tożsamości, obdarzoną swoistymi cechami, mającą określone upodobania, poglądy i preferencje.

Z tak nakreślonej perspektywy autorka przedstawia tutaj wybraną jednostkę językową - wyraz skrzydło (częściej używany, ze względu na parzystość tego narządu, w formie liczby mnogiej skrzydła) oraz formy przymiotnika skrzydlaty, które występują w zbiorze tekstów jednego pisarza. Nie przypadkiem jest nim Stefan Żeromski, ponieważ on potrafił zawrzeć w swoim piśmiennictwie niespotykane gdzie indziej w literaturze polskiej bogactwo słownictwa - różnorodnego słowotwórczo, semantycznie i funkcjonalnie.

W badanym zbiorze znalazło się 257 kontekstów, w których pojawił się wyraz skrzydło i pochodne - w różnych znaczeniach podstawowych i wtórnych oraz w metaforycznych funkcjach tekstowych.

\section{The wings - a means of expression and a vehicle of symbols in the writings of Stefan Żeromski}

\section{Su m m ary}

The linguistic material of the belles-lettres texts can be, and quite often is, variously perceived by the researchers. The linguists most frequently pay attention to the lexical elements, specific nomenclature, particular grammatical forms or the word-formation, as well as to the textual functionality of the lexemes, forms or their groups, or thematic sets. Some linguists also trace the rhetorical devices, particularly the metaphors and comparisons. Less frequently the analyses go beyond the literary text as a basis of the research exploration, i. e. beyond the relationship text - researcher. However, the broader approach, which takes into account the trilateral relationship writer - text - researcher, allows to grasp more aspects of nearly every problem or subject under examination. Additionally, the writer should be perceived here not only as an author or creator of the text, the message sender, the creator of his genuine writing craft, but also as a human individual, existing in a particular time and place/places, a personality, endowed with a concrete identity, specific traits, likings, opinions, and preferences.

From such perspective the author presents here the selected linguistic unit - the word wing (more frequently, because of the nature of this paired organ, used in plural - wings) and the adjectival forms winged, as they occur in the set of texts of one writer. Quite not incidentally this writer is Stefan Żeromski, as he was capable of encompassing in his writings the lexical wealth, unparalleled elsewhere in the Polish literature - diverse as it in the word-formation, semantic, and functional aspects.

The examined set include 257 contexts in which the word wing and its derivatives have occurred - with their various basic and secondary meanings, as well as the metaphoric textual functions. 